\title{
QUALITY CHARACTERISTICS OF BISCUIT PREPARED FROM WHEAT AND MILK THISTLE SEEDS (SILYBUM MARIANUM (L) GAERTN) FLOUR
}

\author{
Amina Menasra ${ }^{1 *}$ and Djamel Fahloul ${ }^{1}$ \\ ${ }^{1}$ Laboratory of Food Science (LSA), Department of Food Technology, \\ Institute of Veterinary Sciences and Agronomic Sciences, University Hadj Lakhdar -Batna 1- (UHB1), Algeria. \\ "menasraamina@gmail.com \\ https://doi.org/10.34302/crpjfst/2019.11.4.1 \\ Article history: \\ Received: \\ 9 February 2019 \\ Accepted: \\ 28 September 2019 \\ Keywords: \\ Biscuit; \\ Enrichment; \\ Milk thistle; \\ Properties.

\section{ABSTRACT} \\ Milk thistle (Silybum marianum) is a rich source of ingredients, such as \\ minerals, aminoacids, fatty acids and phytochemicals exhibiting \\ nutraceutical effects on human health. In this work, roasted milk thistle seeds \\ flour was replace wheat flour to improve biscuit quality. The influence of \\ $10 \%$ addition of milk thistle seeds flour on biscuit quality was studied by \\ analyzing the physicochemicals and sensory properties in order to further \\ exploit the functionality of milk thistle seeds in bakery products. Comparing \\ control and enriched biscuits, we see major differences in terms of quality. \\ Enriched biscuit has a smaller values of weight (6.63g), of spread ratio (6.38) \\ and of density $\left(0.49 \mathrm{~g} / \mathrm{cm}^{3}\right)$, with a bigger volume $\left(13.48 \mathrm{~cm}^{3}\right)$, a dark crust \\ ( $\mathrm{L}^{*}:$ 64.43), a slight milk thistle seeds taste, and with an important \\ nutritional intake (ash : $2.33 \%$, starch : $60.69 \%$, gluten : $28.23 \%$ ). Finally, \\ Milk thistle seeds flour can be used for biscuit enrichment.
}

\section{Introduction}

Bakery products are one of the most profitable segments in supermarket retailing. Biscuits are convenient food products, becoming very popular among both rural and urban populations of worldwide. Some of the reasons for such wide popularity are low cost among other processed foods, varied taste, easy availability and longer shelf life (Dayakar Rao and Bhargavi, 2017).

Over the years, a number of studies have been reported to improve nutritive value of biscuits by incorporating bean, sesame seeds, chickpea, barley, cowpea, lupine, soy protein and corn fiber (Serrem, 2010; Hyun-Jung et al., 2014).

Milk thistle seeds are better known as having medicinal benefits. Milk thistle is used internally in the treatment of liver and gall bladder diseases, jaundice, cirrhosis, hepatitis and poisoning (Aliyas, 2015). Numerous studies have shown that seeds are rich in proteins, lipids and total carbohydrates (Abu Jadayil et al. 1999; Abd Raboh, 2012). Milk thistle seeds can be used as food. It is a great tonic, increases appetite and aids in digestion. Seeds of milk thistle is a good source of minerals. Presences of rich amount of calcium and magnesium are a special feature (Aliyas, 2015). The importance of milk thistle seeds in human nutrition will also increase, as growing number of consumers are looking for products with pro-health properties (Andrzejewska et al., 2015). Up to now, information on incorporation of milk thistle seeds flour in bakery products is scarce (Aliyas, 2015). The addition of milk thistle may be a littleknown for its properties (Brodowska et al., 2014). Apostol et al. (2017) was study the properties of the mixture of wheat and milk thistle seeds flours. Moreover, Sadowska (2006) and Shahat et al. (2016) were examined the effect of milk thistle adding on 
bread quality. Furthermore, Brodowska et al. (2014) reported that the levels of silymarin added were selected to be not higher than $10 \%$ of medicinal dose.

However, no work has been done on the effect of milk thistle seeds (Silybum marianum (1) Gaertn) flour addition on biscuit quality.

The objective of this work was to characterize the mixture of wheat and milk thistle seeds flours through evaluation of physicochemical and sensory properties of biscuit, which are main quality attributes of this mixture for use in bakery. Moreover, differents properties of prepared biscuits were compared using principal component analysis method (PCA).

\section{Materials and methods}

\subsection{Materials}

Soft wheat flours $(72 \%)$ were obtained from Aures Flour Mills Company, Batna cityAlgerria. Milk thistle seeds (Silybum marianum (1) Gaertn) were collected in Bouhmar region of Batna city, located in northeast of Algeria, during 2017 Autumn season. Hydrogenated vegetable shortening, grained sucrose, salt, Ammonium bicarbonate $\left(\mathrm{NH}_{4} \mathrm{HCO}_{3}\right)$, Sodium bicarbonate $\left(\mathrm{NaHCO}_{3}\right)$ and mineral water were obtained from supermarket. Biscuit ingredient and milk thistle seeds were stored at $4^{\circ} \mathrm{C}$ until testing. All reagents and chemicals used in the experimental work were of analytical grade and were purchased from Sigma Co. (St. Louis, MO, USA).

\subsection{Methods}

\subsubsection{Milk thistle seeds flour preparation}

Milk thistle seeds were roasted in a convention electric oven (R-5550, Sharp, Osaka, Japan) for 7 minutes at $130 \pm 2^{\circ} \mathrm{C}$ (degree celsius) (Pandey and Awasthi, 2015). The roasted milk thistle seeds were grounded in laboratory mill and sieved (one millimeter), to obtain a fine homogeneous flours. Samples were stored at $4^{\circ} \mathrm{C}$ until analysis.
2.2.2. Physicochemical and functional poperties of wheat and milk thistle seeds flours

Moisture content was determined according to AACC Method 44 19.01 (AACC, 2000). Ash content was measured according to AACC Method 930.22 using muffle furnace at 450$500^{\circ} \mathrm{C} \quad$ (AACC, 2000). Flours were characterized for $\mathrm{pH}$ according to AACC Method 02-52 (AACC, 2000). Total titratable acidity (TTA) was determined by a Sodium hydroxide

$(\mathrm{NaOH})$ titration according to AOAC (2005). Total starch content was measured by polarimetric method (Korus et al., 2015). Color of flour was determined according to Francis (1998).

Bulk density was determined as described by Chinma et al. (2009). Water and oil absorption capacities were measured as determined by Zouari et al. (2016). Emulsifying and foaming capacity were defined as described by Elkhalifa and Bernhardt (2010). Swelling capacity was measured as determined by Mateos-Aparicio et al. (2010).

\subsubsection{Biscuit preparation}

Control and enriched biscuit with 10\% supplementation level of milk thistle seeds flour were prepared according to AACC Method 10.50 with slight modeifications (AACC, 2000). The recipe contains $80.0 \pm 2 \mathrm{~g}$ standard wheat flour, $35.0 \pm 2 \mathrm{~g}$ (gram) grained sucrose, $20.0 \pm 2$ $\mathrm{g}$ hydrogenated vegetable shortening, $1.0 \pm 2 \mathrm{~g}$ Sodium chloride $(\mathrm{NaCl}), 0.4 \pm 2 \mathrm{~g}$ Ammonium bicarbonate $\left(\mathrm{NH}_{4} \mathrm{HCO}_{3}\right), \quad 0.8 \pm 2 \mathrm{~g}$ Sodium bicarbonate $\left(\mathrm{N}_{\mathrm{a}} \mathrm{HCO}_{3}\right)$ and $17.6 \pm 2 \mathrm{~mL}$ (milliliter) of water. Biscuits dough was sheeted and cut into circular shapes using a cutter (Reddy et al., 2005).

\subsubsection{Biscuit baking}

Control and enriched biscuits were baked in an electrical baking oven (Teba High-01 Inox) under convection conditions at $180^{\circ} \mathrm{C}$ for $15 \pm 2$ minutes (Sakin et al., 2007). 


\subsubsection{Physicochemical properties of biscuits}

Control and enriched biscuits with 10\% supplementation level of milk thistle seeds flour were analyzed for moisture and ash contents according to AACC Methods 44-19 and 40-70, by gravimetric method at $105{ }^{\circ} \mathrm{C}$ and incineration at $550{ }^{\circ} \mathrm{C}$, respectively (AACC, 2000). $\mathrm{pH}$ determination was carried by mixing $5 \mathrm{~g}$ of biscuit sample with $100 \mathrm{ml}$ of freshly boiled distilled water (cooled to a temperature of $40 \pm 5^{\circ} \mathrm{C}$ ). The mixture was left for $1 \mathrm{~h}$ (hour), with regular mixing every 15 minutes. Afterward, $\mathrm{pH}$ was measured using a $\mathrm{pH}$-meter Schott CG 843 with a combined electrode BlueLine 11 (Schott Geräte GmbH, Mainz, Germany) (Budryn et al., 2013). Total titratable acidity was determined as described by Rizzello et al. (2010). Starch content was measured by polarimetric method (Korus et al., 2015). Gluten was estimated by a Sodium hydroxide $(\mathrm{NaOH})$ titration according to AACC Method 38-10 (AACC, 2000). Measurement of upper surface color of biscuits was carried out using a colorimeter (CR-10, Konica Minolta Sensing Inc., Osaka, Japan). Results were expressed using the CIELab system. The following parameters were determined: leightness $\left(\mathrm{L}^{*}=0\right.$ black, $\mathrm{L}^{*}=100$ white $)$, redness $\left(\mathrm{a}^{*}<0\right.$ : green, $\mathrm{a}^{*}>0$ : red), yellowness $\left(\mathrm{b}^{*}<0\right.$ : blue, $\mathrm{b}^{*}>0$ : yellow). Total color change $(\Delta \mathrm{E})$, was calculated from the following equation taking dough color as a reference, denoted by $\mathrm{L}_{0}{ }^{*}, \mathrm{a}_{0}{ }^{*}$ and $\mathrm{b}_{0}{ }^{*}$ :

$$
\begin{gathered}
\Delta \mathrm{E}=\left[\left(L^{*}-L_{0}^{*}\right)^{2}+\left(a^{*}-a_{0}^{*}\right)^{2}+\right. \\
\left.\left(b^{*}-b_{0}^{*}\right)^{2}\right]^{1 / 2}(1)
\end{gathered}
$$

hue angle $\left(\mathrm{h}^{\circ}\right)$ and chroma $\left(\mathrm{c}^{*}\right)$ of biscuits were determined. Three measurements per cookie were taken and reported as average (Sakin-Yilmazer et al. 2013). Results were used to calculate the browning index (BI value) from equation (2):

$$
\mathrm{BI}=\frac{\left[100 \times\left(\frac{a+1.79 L}{5.645 L+a-3.012 b}\right)-0,31\right]}{0,17}
$$

Whiteness index (WI) values of biscuits were measured as described by Zucco et al. (2011) as follows:

$$
\mathrm{WI}=100-\sqrt{\left(100-L^{*}\right)^{2}+a^{2}+b^{2}}
$$

\subsubsection{Physicals dimensions of biscuits (baking quality)}

Diameter (width) and thickness of biscuits were determined according to AACC Method 10-53 (AACC, 2000). Spread ratio was calculated according to Youssef and Mousa (2012) using the following equation:

$$
\text { Spread ratio }=\frac{\text { diameter }}{\text { thickness }}
$$

Weight loss (WL) during baking was measured using the following equation:

$$
\mathrm{WL}=\frac{\left(\mathrm{W}_{\text {dough }}-\mathrm{W}_{\text {biscuit }}\right)}{\mathrm{W}_{\text {dough }}} \times 100
$$

Where, W is biscuits weight (g) (AgraharMurugkar et al., 2015). Volume (V) in cubic centimeter $\left(\mathrm{cm}^{3}\right)$ was calculated as a function of radius (r) (Serrem, 2010):

$$
\mathrm{V}\left(\mathrm{cm}^{3}\right)=\mathrm{r}^{2} \times \text { thickness } \times 3.14
$$

Biscuits density was determined and expressed as $\mathrm{g}$ per $\mathrm{cm}^{3}$ (Serrem, 2010; Sozer et al., 2014):

$$
\mathrm{D}\left(\frac{\mathrm{g}}{\mathrm{cm}^{3}}\right)=\frac{\text { mass }}{\text { Volume }}
$$

\subsubsection{Sensory evaluation of biscuits}

Sensory analysis of biscuits was carried out by 10 non-trained panelists from Food Sciences Laboratory in Food Technology Department. Samples presentation to panelists was at random and one at a time. Panelists were given enough water to rinse their mouths between each serve (Galla et al., 2007). Sensory evaluation was carried out on control and enriched biscuits. 
Evaluated attributes were appearance, color, texture, taste, odor and overall acceptability. For each sample, panelists scored their liking of characteristics using nine point hedonic scale (Agrahar-Murugkar et al., 2015). Panelists scored for different properties with a maximum score of 9 for like extremely, 8-like very good, 7-like good, 6-like moderately, 5-neither like nor dislike, 4-dislike moderately, 3- dislike fairly, 2-dislike very much and 1 for dislike extremely (Galla et al., 2007).

\subsubsection{Statistical analysis}

The experimental data collected in triplicate was analyzed for significant differences with the help of analysis of variance (ANOVA) conducted using SPSS 25.0 software (SPSS Inc., Chicago, IL, USA) (Barak et al., 2014; Mogol and Gökmen, 2014). Furthermore, a principal component analysis (PCA), which is a multivariate approach designed for multicorrelated data, was performed to visualize possible relationships within data matrix. To decide the number of principal components (PCs), the eigenvalues of the correlation matrix, indicating the percentage of variability explained by each component, were tabulated and a scree plot was constructed (Aponte et al., 2014). Principal Component Analysis (PCA) of biscuits properties was completed by statistical software, STATISTICA version 10.0 (StatSoft, France) (Onacik-Gür et al., 2015).

\section{Results and discussions}

\subsection{Physicochemical and funtcional properties of flours}

Physicochemical and functional properties of wheat and milk thistle seeds flours are presented in Table 1. Moisture content of flours was found to lie in the acceptable limits $(0-13 \%)$. Values lie within the limits that enable safe storage (Yusuf et $a l ., 2008)$. The level of moisture content of wheat flour $(9.48 \%)$ is close to that obtained amount $(10.23 \%)$ by Oppong et al. (2015) of soft wheat flour. The moisture content of milk thistle seeds flour was the lowest $(7.53 \%)$ and was significantly $(\mathrm{P} \leq 0.05)$ different from wheat flour (Table 1). Abu Jadayil et al. (1999) found that milk thistle seeds contained $5.8 \%$ of moisture. Claculated moisture content by AwadAllah (2013) of pine nut meal is 7.9\%.

Wheat flour had low ash content $(0.99 \%)$. This value is close to that reported (1\%) by Oppong et al. (2015). Milk thisle flour contained $3.1 \%$ of ash content. Abu Jadayil et al. (1999) found that milk thistle seeds contains $4.8 \%$ of ash.

Wheat flour had the highest carbohydrates content $(75.76 \%)$. This result is close to that found $(77.9 \%)$ by Ragaee et al. (2006). Milk thistle seeds flour contained $51.4 \%$ of total carbohydrates. Abu Jadayil et al. (1999) found a low values $(24.3 \%$ and $10 \%)$ of carbohydrate in milk thistle and sesame seeds flours, respectively.

Table 1. Physicochemical and functional properties of wheat and milk thistle seeds flours.

\begin{tabular}{|c|c|c|}
\hline Parameters & Wheat flour & $\begin{array}{c}\text { Thistle milk seeds } \\
\text { flour }\end{array}$ \\
\hline Moisture (\%) & $9.48 \pm 0.0057^{\mathrm{aA}}$ & $7.53 \pm 0.0058^{\mathrm{aB}}$ \\
\hline Dry matter (\%) & $90.52 \pm 0.0057^{\mathrm{abcA}}$ & $92.47 \pm 0.0058^{\mathrm{aB}}$ \\
\hline Ash (\%) & $0.99 \pm 0.011^{\mathrm{abcA}}$ & $3.1 \pm 0.057^{\mathrm{aB}}$ \\
\hline Organic matter (\%) & $99.01 \pm 0.011^{\mathrm{abcA}}$ & $96.9 \pm 0.057^{\mathrm{aB}}$ \\
\hline Total starch (\%) & $75.76 \pm 0.0057^{\mathrm{bcA}}$ & $51.4 \pm 0.1^{\mathrm{aB}}$ \\
\hline Color & $99.6 \pm 0.058^{\mathrm{cA}}$ & $72.8 \pm 0.1^{\mathrm{aB}}$ \\
\hline Bulk density (g/cm $\mathbf{3})$ & $0.72 \pm 0.008^{\mathrm{abcA}}$ & $0.08 \pm 0.01^{\mathrm{aB}}$ \\
\hline Oil absorption capacity (g/g) & $1.50 \pm 0.002^{\mathrm{aA}}$ & $1.01 \pm 0.01^{\mathrm{aB}}$ \\
\hline Emulsion capacity (\%) & $62.2 \pm 0.3^{\mathrm{abcA}}$ & $42.69 \pm 0.015^{\mathrm{aB}}$ \\
\hline
\end{tabular}




\begin{tabular}{|c|c|c|}
\hline Foam capacity (\%) & $13.53 \pm 0.035^{\mathrm{bA}}$ & $4.4 \pm 0.4^{\mathrm{aB}}$ \\
\hline Swelling capacity (\%) & $7.50 \pm 0.4^{\mathrm{aA}}$ & $6.73 \pm 0.0057^{\mathrm{aB}}$ \\
\hline
\end{tabular}

Values followed by different letters (lower-case letters in the same column, and upper-case letters in the same line) are significantly different at $5 \%$ level of significance $(\alpha<0.05)$.

Color value of wheat flour (99.63) is higher than milk thistle seeds flour (72.8). Milk thistle seeds flour was darker than wheat flour (WF). Eke- Ejiofor et al. (2014) reported that jackfruit seeds flour had a color equal $74.79 \%$. Flour extracted under perfect conditions is pure white in color and it is an important criterion for flour quality (Eke- Ejiofor et al., 2014).

Bulk density of wheat flour $\left(0.72 \mathrm{~g} / \mathrm{cm}^{3}\right)$ is close to that reported by Baljeet et al. (2014) $\left(0.70 \mathrm{~g} / \mathrm{cm}^{3}\right)$. Obtained bulk density $(0.08$ $\mathrm{g} / \mathrm{cm}^{3}$ ) of milk thistle seeds flour was lower than wheat flour. The low bulk density of flour could be attributed to the relatively lower protein content (gluten-free) (Korus et al., 2015; Oppong et $a l ., 2015)$.

Wheat flour had a higher water absorption capacity $(1.50 \mathrm{~g} / \mathrm{g})$ than milk thistle seeds flour $(1.01 \mathrm{~g} / \mathrm{g})$. Water absorption capacity of wheat flour is similar to that reported $(1.50 \mathrm{~g} / \mathrm{g})$ by Oppong et al. (2015). Awad-Allah (2013) found water absorption capacity of pine nut meal equal $1.4 \mathrm{~g} / \mathrm{g}$. Flour with high water absorption capacity would be useful in foods such as bakery products which require hydration to improve handling features (Oppong et al. (2015).

Wheat flour had a higher oil absorption capacity $(1.03 \mathrm{~g} / \mathrm{g})$ compared to milk thisle seeds flour $(0.99 \mathrm{~g} / \mathrm{g})$. Oil absorption capacity of wheat flour is similar to that found $(1 \mathrm{~g} / \mathrm{g})$ by Oppong et al. (2015). Awad-Allah (2013) reported oil absorption capacity of pine nut and walnut meals equal 1.3 and $1.2 \mathrm{ml} / \mathrm{g}$, respectively. Flour with high oil absorption capacity could be useful in food formulation where oil holding capacity is needed such as sausage and bakery products (Oppong et al. (2015).

Emulsion capacity of wheat flour $(62.2 \%)$ is lower than found $(42.77 \%)$ by Zouari et al. (2016). Milk thistle flour had a lower emulsion capacity (42.69\%). Awad-Allah (2013) mentioned emulsion capacity of pine nut meal equal $63.6 \mathrm{ml} / \mathrm{g}$.

Wheat flour had a higher foam capacity $(13.53 \%)$. This result is close to that found (13.19\%) by Zouari et al. (2016). Foam capacity (FC) of milk thistle seeds flour is $4.4 \%$. The higher value of foam propertie might be due to the high starch content (Awad-Allah, 2013). Foam capacity is important for flour used in many leavening food products such as baked goods, cakes and biscuits (Elkhalifa and Bernhardt, 2010).

Wheat flour had the higher value of swelling capacity $(7.50 \mathrm{ml} / \mathrm{g})$. This result is similar to that found by Oppong et al. (2015). Swelling power of milk thistle seeds flour is $6.73 \%$. Flour with high swelling capacity could be useful in food systems where swelling is required (Oppong et al., 2015).

\subsection{Physical dimensions of biscuits (baking quality)}

Results of various physical dimensions of biscuits are shown in Table 2. Control biscuit had a higher values of weight $(7.17 \mathrm{~g})$ and weight loss $(15.25 \%)$ than enriched biscuit with milk thistle seeds flour. Serrem (2010) found a reduction in weight of enriched biscuit with soy flour. The reduction of total solids in dough results biscuit has lower weight (Serrem, 2010). Control biscuit had the highest spread ratio (7.24). When more free water exists, internal dough viscosity becomes lower and thus spread factor of baked cookies increased (Hyun-Jung et al., 2014). Difference in spread ratio depends on source of flours substitution. Cookies having higher spread ratio are considered the most desirable (Hyun-Jung et al., 2014). It can be seen that biscuits density seemed to be affected by milk thistle flour addition $\left(0.49 \mathrm{~g} / \mathrm{cm}^{3}\right)$. Density is considered the best index of sensory texture of biscuits (Mamat and Hill. 2014). 
Table 2. Physicochemical properties of biscuits.

\begin{tabular}{|c|c|c|}
\hline Parameters & CB & BTMSF \\
\hline Weight (g) & $7.17 \pm 0.02^{\mathrm{dA}}$ & $6.63 \pm 0.152^{\mathrm{dB}}$ \\
\hline Weight loss (\%) & $15.25 \pm 0.042^{\mathrm{fA}}$ & $14.11 \pm 0.32^{\mathrm{gB}}$ \\
\hline Diameter $(\mathrm{mm})$ & $48.03 \pm 0.1527^{\mathrm{iAB}}$ & $47.86 \pm 0.152^{\mathrm{jAB}}$ \\
\hline Thickness (mm) & $6.63 \pm 0.1527^{\mathrm{dA}}$ & $7.5 \pm 0.2^{\mathrm{eB}}$ \\
\hline Volume $\left(\mathrm{cm}^{3}\right)$ & $12.015 \pm 0.353^{\mathrm{eA}}$ & $13.48 \pm 0.342^{\mathrm{fB}}$ \\
\hline Spread ratio & $7.24 \pm 0.142^{\mathrm{dA}}$ & $6.38 \pm 0.178^{\mathrm{dB}}$ \\
\hline Density $\left(\mathrm{g} / \mathrm{cm}^{3}\right)$ & $0.59 \pm 0.0157^{\mathrm{cA}}$ & $0.49 \pm 0.02^{\mathrm{cB}}$ \\
\hline Moisture (\%) & $4.76 \pm 0.057^{\mathrm{oA}}$ & $4.43 \pm 0.115^{\mathrm{pB}}$ \\
\hline Dry matter (\%) & $95.24 \pm 0.057^{\mathrm{bA}}$ & $95.57 \pm 0.115^{\mathrm{bB}}$ \\
\hline Ash (\%) & $1.25 \pm 0.1^{\mathrm{pA}}$ & $2.33 \pm 0.20^{\mathrm{qB}}$ \\
\hline Organic matter $(\%)$ & $98.75 \pm 0.1^{\mathrm{dA}}$ & $97.67 \pm 0.02^{\mathrm{dB}}$ \\
\hline $\mathrm{pH}$ & $6.61 \pm 0.02^{\mathrm{aA}}$ & $6.38 \pm 0.02^{\mathrm{aB}}$ \\
\hline TTA (\%) & $0.25 \pm 0.01^{\mathrm{kA}}$ & $0.33 \pm 0.0152^{1 \mathrm{~B}}$ \\
\hline Starch (\%) & $66.78 \pm 0.01^{\mathrm{gA}}$ & $60.69 \pm 0.01^{\mathrm{hB}}$ \\
\hline Dry gluten (\%) & $32.33 \pm 0.02^{1 \mathrm{~A}}$ & $28.23 \pm 0.152^{\mathrm{mB}}$ \\
\hline $\mathbf{L}^{*}$ & $74.033 \pm 0.57^{\mathrm{hA}}$ & $64.43 \pm 0.30^{\mathrm{iB}}$ \\
\hline $\mathrm{c}^{*}$ & $36.87 \pm 0.095^{\mathrm{nA}}$ & $30.096 \pm 0.072^{\mathrm{oB}}$ \\
\hline $\mathbf{h}^{\circ}$ & $85.76 \pm 0.152^{\mathrm{mA}}$ & $84.76 \pm 0.152^{\mathrm{nB}}$ \\
\hline$\Delta \mathbf{E}$ & $82.71 \pm 0.554^{q \mathrm{~A}}$ & $71.11 \pm 0.25^{\mathrm{rB}}$ \\
\hline BI & $248.99 \pm 0.702^{\mathrm{jA}}$ & $254.66 \pm 0.553^{\mathrm{kB}}$ \\
\hline WI & $54.89 \pm 0.264^{\mathrm{A}}$ & $53.40 \pm 0.27^{\mathrm{B}}$ \\
\hline
\end{tabular}

TTA: total titratable acidity, $\mathrm{L}^{*}:$ leightness, $\mathrm{c}^{*}:$ chromaticity, $\mathrm{h}^{\circ}:$ hue angle, $\Delta \mathrm{E}$ : total color change, $\mathrm{BI}:$ browning index, WI : whiteness index, CB: control biscuit, BTMSF: enriched biscuit with milk thistle seeds flour. Values followed by different letters (lower-case letters in the same column, and upper-case letters in the same line) are significantly different at $5 \%$ level of significance $(\alpha<0.05)$.

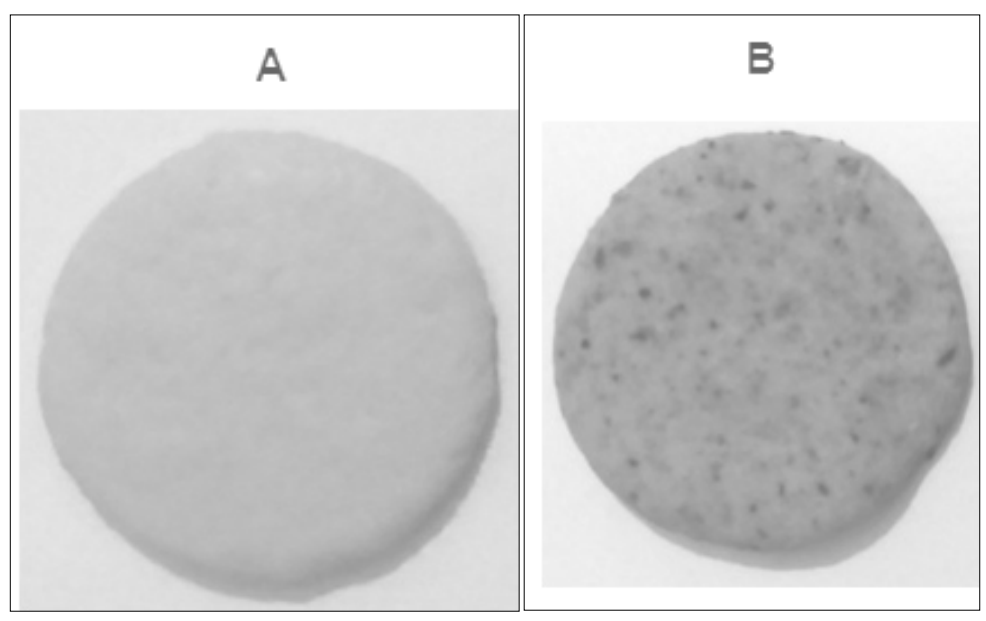

Figure 1. Control biscuit (A) and enriched with milk thistle seeds flour (B). 


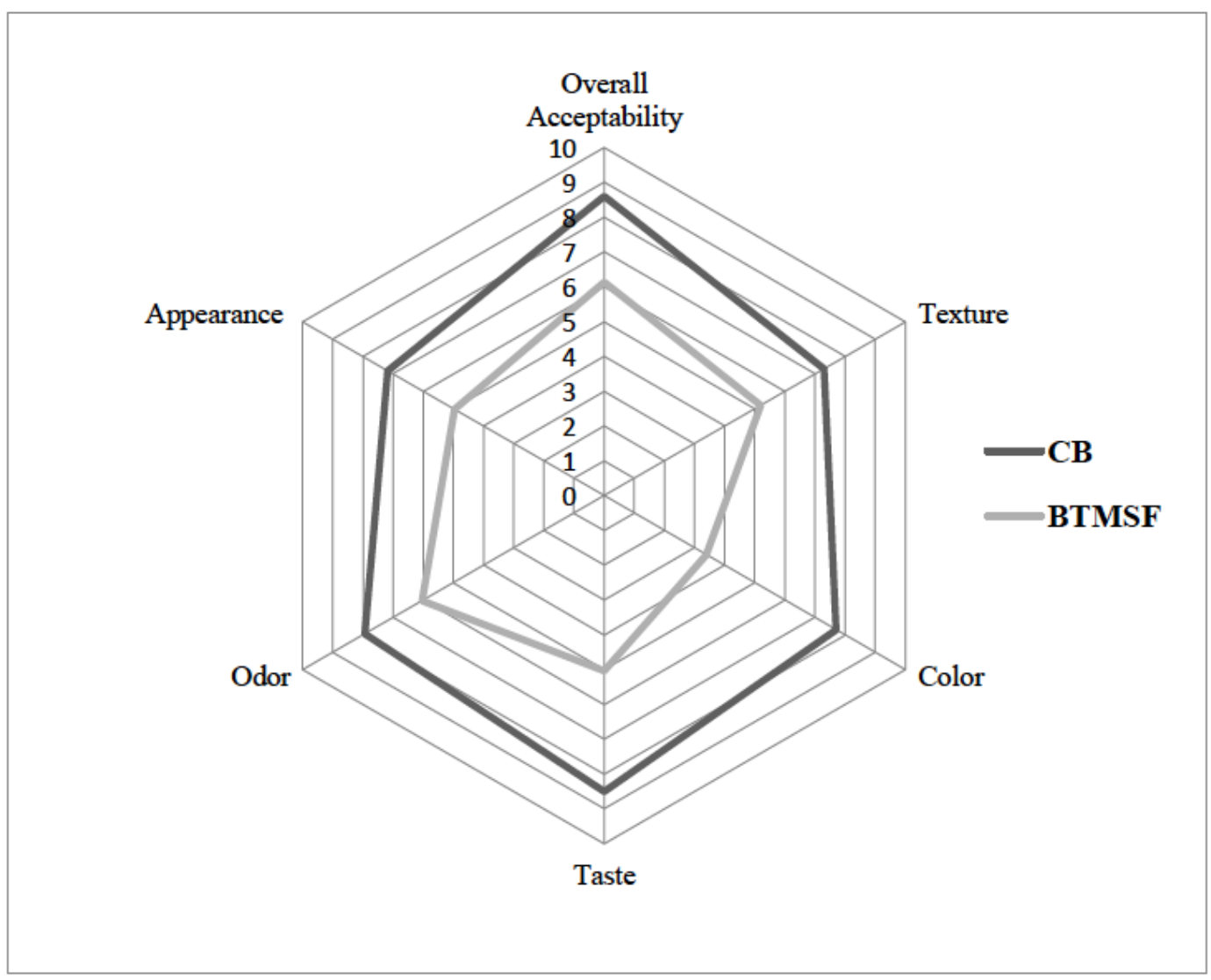

Figure 2. Spider diagram of sensory evaluation of biscuits.

CB: control biscuit, BMTSF : enriched biscuit with milk thistle seeds flour. Scores are based on a 9point hedonic scale with 1, dislike extremely; 5, neither like nor dislike; and 9, like extremely; number of panelists $(\mathrm{n})=10$.

Brodowska et al. (2014) reported that added doses of $0.16 \mathrm{~g}, 0.33 \mathrm{~g}$ and $0.56 \mathrm{~g} / 100 \mathrm{~g}$ of milk thistle fruit did not influence physical properties of wheat dough of bread. Also, the levels of silymarin added were selected to be not higher than $10 \%$ of medicinal dose (Brodowska et al., 2014).

\subsection{Physicochemical properties of biscuits}

Table 2 shows physicochemical properties of control and enriched biscuits. Eenriched biscuit with milk thistle seeds flour had lower moisture content $(4.43 \%)$ than control biscuit $(4.76 \%)$. This is due to lowest moisture content of milk thistle seeds flour compared to wheat flour (Table 1). The reduction of total solids in dough results biscuit has lower weight (Serrem, 2010).
Enriched biscuit with milk thistle seeds flour contain a higher value of ash (2.33\%). Difference in ash content between control and enriched biscuits is certainly due to flour quality. Serrem (2010) found an increase in ash content of enriched biscuit with soy flour. Ash content of biscuit could be raised if milk thistle seeds flour is incorporated. This finding showed that addition of milk thistle flour in cereal products enhanced their nutritional values.

Found $\mathrm{pH}$ values are very close (Table 2). This confirms acidity results which also showed a slight difference. $\mathrm{pH}$ decreased and total titratable acidity was slightly increased in enriched biscuit with milk thistle seeds flour. Rizzello et al. (2010) reported a decrease in $\mathrm{pH}$ with an increase in total titratable acidity of 
prepared bread with fermented wheat germ flour.

Enriched biscuit with milk thistle flour had a lower starch content (Table 2). This decrease in starch content could be explained by the low carbohydrate content of flour. Similarly, Serrem (2010) found a decrease in starch content of enriched biscuit with soy flour.

Low value of dry gluten content was found in enriched biscuit with milk thistle seeds flour compared to control biscuit. This effect is a selfevident result from the substitution of wheat flour with milk thistle flour. Similarly, Hallén et al. (2004) found a decrease in gluten content of enriched biscuit with cowpea flour.

Cookies color was generated mainly during baking process from Maillard reaction between reducing sugars and protein (Hyun-Jung et al., 2014). Substituting wheat flour with milk thistle seeds flour in biscuit formulation affects significantly surface color of biscuit. Biscuit crust became brown with milk thistle flour addition (Figure 1). Thus, enriched biscuit had a low value of leightness $\left(\mathrm{L}^{*}: 64.43\right)$ compared to control biscuit. Similarly, Sozer et al. (2014) mentioned that biscuit became darker with bran flour adding. Color difference $\left(\Delta \mathrm{E}^{*}: 71.11\right)$ decreased but chromaticity ( $\left.\mathrm{c}^{*}: 30.096\right)$ and hue angle $\left(h^{\circ}: 84.76\right)$ values increased when milk thistle seeds flour added to biscuit. These results are similar to thoses reported by Hegazy et al. (2014) for enriched biscuits with chestnut flour. Enriched biscuit had a higher value of browning index (BI : 254.66) compared to control biscuit. Acrylamide formation and concentration during biscuit baking was generally reported to have correlation with brown surface formation (Sakin-Yilmazer et al., 2013). Thermal degradation of originally colourless complex polyphenols to coloured phenols during baking increases browning index (BI) of enriched biscuit. The increase in brown index of enriched biscuit with milk thistle seeds flour may be ascribed to polyphenoloxidases activity as a result of biscuit baking (Jimoh et al., 2009). Whiteness index decreased in enriched biscuit with milk thistle seeds flour (WI : 53.40). Similarly, Zucco et al. (2011) observed a reduction in whiteness index values of cookies as the level of pulse flour substitution increased. Also, Ostermann-Porcel et al. (2017) found a reduction of whiteness index (WI) of enriched cookies with okara flour. The higher the whiteness index the whiter the sample (Zucco et al., 2011).

\subsection{Sensory characteristics}

The effect of adding of milk thistle seeds flour to wheat flour on sensory properties of biscuit was evaluated and presented in Figure 2. Control biscuit had the highest ratings for all tested sensory parameters. Results indicated that, adding natural milk thistle seeds flour to biscuit led to decrease of sensory scores of color, appearance and taste. In the same time odor, texture and overall acceptance of enriched biscuit with milk thistle seeds flour are not more affected significantly. Hegazy et al. (2014) reported similar results for enriched biscuit with natural chestnut (Castanea sativa Mill.) flour. Most of panelists reported that biscuit becam brown with milk thistle flour addition in biscuit. Moreover, they mentioned that enriched biscuit gives a sense to the presence of remains of thin tissue in tongue. This may be related to the presence of some seeds coat of the milk thistle. These results are in agreement with Abd Raboh (2012). Hyun-Jung et al. (2014) reported that taste is important characteristic in determining cookies acceptability. Also, Heinio et al. (2016) mentioned that raw materials and ingredients are the key factor for flavour formation of of cereal foods.

Brodowska et al. (2014) reported that added doses of $0.16 \mathrm{~g}, 0.336 \mathrm{~g}$ and $0.56 \mathrm{~g} / 100 \mathrm{~g}$ of milk thistle fruit did not influence sensory properties of wheat dough of bread.

\subsection{Principal component analysis (PCA) of biscuits properties}

Relationships between biscuits properties were obtained using factorial principal component analysis (PCA). Original data set was renormalized by an autoscaling transformation (data not shown) and different parameters were analyzed by a multivariate approach (Popovic et 
al., 2013). The two first principal components (PCs) were sufficient to explain the maximum variation in all original data. Figure 3 shows plots of loadings (Figure 3A) and scores (Figure 3B) obtained from PCs, where the first two principal components (PC1 and PC2) accounted for $96.32 \%$ of the total variance of data. In particular, PC1 explained $92.88 \%$ of the variation of the data, while PC2 explained $3.44 \%$ (Aponte et al., 2014). For Figure 3A, in the unit circle, parameters (moisture $(\mathrm{M})$, dry matter (DM), ash (A), organic matter (OM), $\mathrm{pH}$, total titratable acidity (TTA), starch (S), dry gluten (DG), weight (W), weight loss (WL), thickness (Thk), spread ratio (SR), volume (V), density (Ds), total color change $(\Delta \mathrm{E})$, leightness $\left(\mathrm{L}^{*}\right)$, hue angle $\left(\mathrm{h}^{\circ}\right)$, chromaticity $\left(\mathrm{c}^{*}\right)$, browning index (BI), wheitness index (WI), overall acceptance (Ov Acc), texture (Txt), color (Col), taste (Tst), Odor (Od) and appearance (App)) are well presented in the first axis than diameter (D) parameter in second axis. Figure 3A divided the previous parameters very well in the following way:

- $\quad$ Axis 1, for PC1:

- $\quad$ Thickness (Thk), total titratable acidity (TTA), volume (V), dry matter (DM) and ash (A) are strongly negatively correlated with moisture $(\mathrm{M})$, organic matter $(\mathrm{OM}), \mathrm{pH}$, starch (S), dry gluten (G), weight (W), weight loss (WL), spread ratio (SR), density (Ds), total color change $(\Delta \mathrm{E})$, leightness $\left(\mathrm{L}^{*}\right)$, hue angle $\left(\mathrm{h}^{\circ}\right)$, chromaticity $\left(\mathrm{c}^{*}\right)$, browning index (BI), wheitness index (WI), overall acceptance (Ov Acc), taste (Tst), texture (Txt), color (Col) and appearance (app). These variables contribute strongly to the formation of axis 1 (Popovic et al., 2013) ;

- $\quad$ Thickness (Thk), total titratable acidity (TTA), volume (V), dry matter (DM) and ash (A) have a great effect on $\mathrm{PC} 1$ than moisture (M), organic matter (OM), $\mathrm{pH}$, starch (S), dry gluten (G), weight (W), weight loss (WL), spread ratio (SR), density (Ds), total color change $(\Delta \mathrm{E})$, leightness $\left(\mathrm{L}^{*}\right)$, hue angle $\left(\mathrm{h}^{\circ}\right)$, chromaticity $\left(\mathrm{c}^{*}\right)$, browning index (BI), wheitness index (WI), overall acceptance (Ov Acc), taste (Tst), texture (Txt), color (Col) and appearance (app), because they were positively correlated by $\mathrm{PCl}$ and any increase in these variables produces an increase in $\mathrm{PC} 1$. On the other hand, moisture $(\mathrm{M})$, organic matter $(\mathrm{OM})$, $\mathrm{pH}$, starch (S), dry gluten (G), weight (W), weight loss (WL), spread ratio (SR), density (Ds), total color change $(\Delta \mathrm{E})$, leightness $\left(\mathrm{L}^{*}\right)$, hue angle $\left(\mathrm{h}^{\circ}\right)$, chromaticity $\left(\mathrm{c}^{*}\right)$, browning index (BI), wheitness index (WI), overall acceptance (Ov Acc), taste (Tst), texture (Txt), color (Col) and appearance (app) were negatively correlated by PC1 (Popovic et al., 2013) ;

- Overall acceptance (Ov Acc), spread ratio (SR) and wheitness index (WI) parameters are positioned closely due to the positive correlations among them (Popovic et al., 2013);

- Also, color ( $\mathrm{Col})$ and total color change $(\Delta \mathrm{E})$ parameters are positioned closely due to the significant positive correlations among them (Popovic et al., 2013);

- Moreover, weight (W) and weight loss (WL) parameters are positioned closely due to the positive correlations among them (Popovic et al., 2013);

- $\quad$ Opposite direction of moisture (M), ash (A) and total titratable acidity (TTA) on one side and dry matter (DM), organic matter (OM) ad $\mathrm{pH}$ on another side, indicates that moisture (M), ash (A) and total titratable acidity (TTA) are the major contributors of dry matter (DM), organic matter $(\mathrm{OM})$ and $\mathrm{pH}$, respectively (Popovic et al., 2013).

- Axis 2, for PC2:

- Diameter (D) variable contributes slightly to the formation of axis 2 (Popovic et al., 2013);

- Diameter (D) has a little small effect on PC2 because it was negatively correlated by PC2, and any increase in this variable produces a decrease in PC2 (Popovic et al., 2013). 

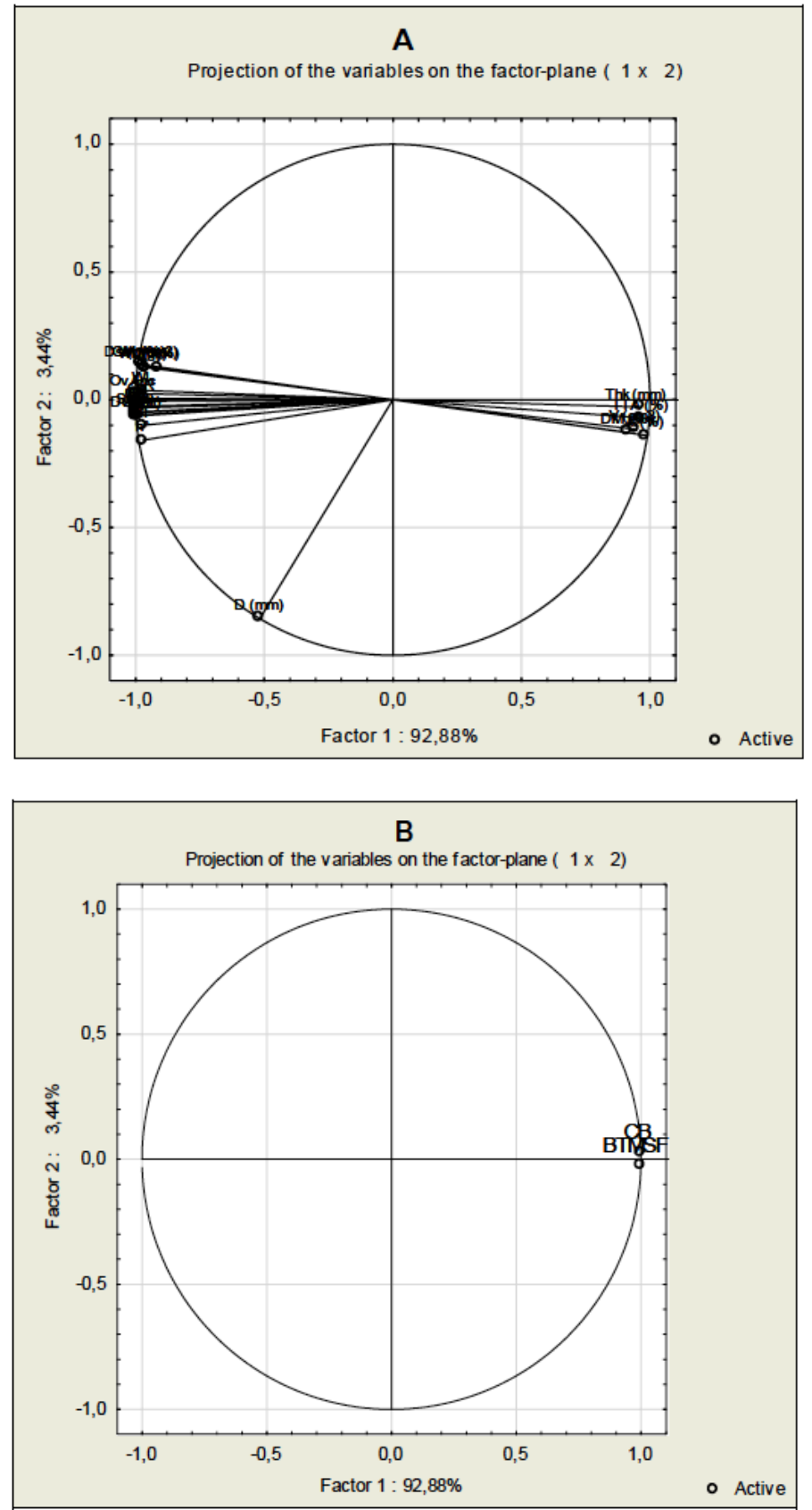

Figure 3. Graph of loading plot of physicochemical and sensory properties (A) and scores plot (B) for biscuits.

M: moisture, DM: dry matter, A: ash; OM: organic matter, TTA: total titratable acidity, S: starch, DG: Dry gluten, W: weight, WL: weight loss, d: diameter, Thk: thickness, V: volume, SR: spread ratio, D: density, $\mathrm{L}^{*}$ : leightness, $\mathrm{h}^{\circ}$ : hue angle, $\mathrm{c}^{*}$ : chromaticity, $\triangle \mathrm{E}$ : total color change, $\mathrm{BI}$ : browning index, WI : whiteness index, CB: control biscuit, BTMSF: enriched biscuit with milk thistle seeds flour.

For Figure 3B, scores distribution allowed for clustering of the samples into two groups (control biscuit (CB) and enriched biscuit with milk thsitle seeds flour (BMTSF)). The difference between these groups is based on PC1 (total titratable acidity (TTA), dry matter (DM), thickness (Thk), ash (A) and volume (V)) (Popovic et al., 2013). All two groups were positively negatvely scored on PC1 (Popovic et al., 2013). Control biscuit (CB) showed positive 
score on PC2 but enriched biscuit with milk thsitle seeds flour (BMTSF) was entirely located in the negative part. In particular, enriched biscuit wih milk thistle seeds flour proved to be strongly characterized by Thickness (Thk), total titratable acidity (TTA), volume (V), dry matter (DM) and ash (A). So, thickness (Thk), total titratable acidity (TTA), volume (V), dry matter (DM) and ash (A) are higher in enriched biscuit with milk thistle seeds flour (BMTSF) than control biscuit (CB).

Results of principal component analysis (PCA) revealed the influence of milk thistle seeds flour addition on physicochemical and sensory properties of biscuit :

$\checkmark$ Dry matter is heigher in enriched biscuit because milk thistle seeds flour had lower moisture content than wheat flour (Table 1). The reduction of total solids in dough results biscuit has lower weight (Serrem, 2010).

$\checkmark$ Enriched biscuit with milk thistle seeds flour contains high value of ash and a low value of organic matter. Hegazy et al. (2014) and Serrem (2010) found an increase in ash content of enriched biscuits with chestnut (Castanea sativa Mill.) and soy flours, respectively. Ash content of biscuit could be raised if milk thistle seeds flour is incorporated. This finding showed that addition of milk thistle seeds flour in cereal products enhanced their nutritional values ;

$\checkmark \mathrm{pH}$ decreased and total titratable acidity increased sleightly in enriched biscuit with milk thistle seeds flour. Rizzello et al. (2010) reported a decrease in $\mathrm{pH}$ with an increase in total titratable acidity of prepared bread with fermented wheat germ flour;

$\checkmark$ Enriched biscuit with milk thistle seeds flour had lower starch content. This decrease in starch content could be explained by the low carbohydrate content of flour. Similarly, Serrem (2010) found a decrease in starch content of enriched biscuit with soy flour ; $\checkmark$ Dry gluten content decreased significantly with milk thistle seeds flour addition in biscuit (Table 2). This effect is a selfevident result from the substitution of wheat flour with milk thistle seeds flour, reducing the amount of gluten in the composite flour. Hallén et al. (2004) found a decrease in gluten content of enriched biscuit with cowpea flour ;

$\checkmark$ It was observed that biscuit made with milk thistle seeds flour had the highest thickness and volume and the least weight, diameter and spread ratio than control biscuit. Difference in spread ratio depends on source of flours substitution. Cookies having higher spread ratio are considered the most desirable (Hyun-Jung et al., 2014);

$\checkmark$ It can be seen that biscuit density seemed to be affected by milk thistle seeds flour addition. Density is considered the best index of sensory texture of biscuits (Mamat and Hill. 2014);

$\checkmark$ Substituting wheat flour with milk thistle seeds flour in biscuit formulation significantly affects surface color of biscuit. Biscuit crust became darker with milk thistle seeds flour addition (Figure 1). Enriched biscuit leightness $\left(\mathrm{L}^{*}\right)$ decreased compared to control biscuit. Similarly, Sozer et al. (2014) mentioned that biscuit became darker with bran flour adding ;

$\checkmark$ Chromaticity and hue angle values increased but color difference $\left(\Delta \mathrm{E}^{*}\right)$ decreased when milk thistle seeds flour was added to biscuit. These results are similar to those found by Hegazy et al. (2014) for enriched biscuit with chestnut flour ;

$\checkmark \quad$ It was observed a general increasing trend in browning index (BI) value of enriched biscuit with milk thistle seeds flour. This increase in browning index was due to acrylamide formation and concentration. Acrylamide concentration was generally reported to have correlation with surface color formation (Sakin-Yilmazer et al., 2013). Also, thermal degradation of 
originally colourless complex polyphenols to coloured phenols during biscuit baking increases biscuits browning index (BI). The increase in browning index of enriched biscuit with milk thistle seeds flour may be ascribed to polyphenoloxidases activity as a result of biscuit baking (Jimoh et al., 2009);

$\checkmark$ As the milk thistle seeds flour added to biscuit, a reduction of whiteness index values was observed. Similarly, Ostermann-Porcel et al. (2017) found that as the okara content increased in cookies formulation, a reduction of whiteness index (WI) values was observed;

$\checkmark$ Biscuits made with wheat had the highest ratings for all tested sensory parameters. Results indicated that, adding of natural milk thistle seeds flour to biscuit led to decrease of sensory scores of color, appearance and taste. In the same time odor, texture and overall acceptance of enriched biscuit with milk thistle seeds flour are not more affected significantly. Hegazy et al. (2014) reported similar results for enriched biscuit with natural chestnut (Castanea sativa Mill.) flour.

$\checkmark$ In addition, milk thistle seeds flour addition may provide additional flavor of milk thistle seeds to cookies which could change consumer's acceptability Abd Raboh (2012).

\section{Conclusions}

The results of this study suggest that milk thistle seeds flour may be blended with wheat flour at levels of $10 \%$ to obtain enriched biscuit. Compared to control biscuit, we see major differences in terms of quality of enriched biscuit (increase in volume $\left(13.48 \mathrm{~cm}^{3}\right)$ with a decrease in weight $(6.63 \mathrm{~g})$, in density $(0.49$ $\mathrm{g} / \mathrm{cm}^{3}$ ) and in spread ratio (6.38)). Also, as milk thistle seeds flour added, biscuit color becam brown (L*: 64.43). Moreover, the characterization performed in this study proved that the milk thistle seeds flour is a valuable source of minerals $(3.1 \%)$, starch $(51.4 \%)$ and it could be used as a natural enrichment of glutenfree bakery product.

\section{References}

Abd Raboh, F. F. (2012). Chemical studies on milk thistle seeds as a novel source of human food. Egypt: Tanta University, PhD thesis.

Abu Jadayil, S., Tukan, S. K. and Takruri, H. R. (1999). Bioavailability of iron from four different local food plants in Jordan. Plant Foods for Human Nutrition, 54(4), 285-294. Agrahar-Murugkar, D., Gulati, P., Kotwaliwale, N. and Gupta, C. (2015). Evaluation of nutritional, textural and particle size characteristics of dough and biscuits made from composite flours containing sprouted and malted ingredients. Journal of Food Science and Technology, 52(8), 5129-5137.

Aliyas, I. M. (2015). Wild Milk Thistle Unique Fatty Plant. International Journal of Science and Research, 6(1), 1227-1229.

American Association of Cereal Chemistry (A.A.C.C.). (2000). Official Methods of Analysis. 9th ed. U.S.A.: St. Paul., Minnesota.

Andrzejewska, J., Martinelli, T. and Sadowska, K. (2015). Silybum marianum: nonmedical exploitation of the species : review article. Annals of Applied Biology, 167, 285297.

Aponte, M., Boscaino, F., Sorrentino, A., Coppola, R. M. P. and Romano, A. (2014). Effects of fermentation and rye flour on microstructure and volatile compounds of chestnut flour based sourdoughs. LWT Food Science and Technology, 58, 387-395. Apostol, L., Iorga, S., Mosoiu, C., Racovita, R. C. and Niculae, O. M. (2017). The effects of partially defatted milk thistle (silybum marianum) seed flour on wheat flour. Journal of International Scientific Publications, Agriculture and Food, 5, 7484.

Association of Official Analytical Chemists (A.O.A.C.). (2000). Official Methods of Analysis. 17th ed. U.S.A.: Arlington, Virginia. 
Awad-Allah, M. A. A. (2013). Evaluation of selected nuts and their proteins functional properties. Journal of Applied Sciences Research, 9(1), 885-896.

Baljeet, S. Y., Ritika, B.Y. and Reena, K. (2014). Effect of incorporation of carrot pomace powder and germinated chickpea flour on the quality characteristics of biscuits. International Food Research Journal, 21(1), 217-222.

Barak, S., Mudgil, D. and Khatkar, B. S. (2014). Effect of flour particle size and damaged starch on the quality of cookies. Journal of Food Science and Technology, 51(7), 13421348 .

Brodowska, M., Guzek, D. and Wierzbicka, A. (2014). Modern technological solutions used in the production of bakery products with high biological value. Advances in Science and Technology Research Journal, 8(22), 83-92.

Budryn, G., Żyżelewicz, D., Nebesny, E., Oracz, J. and Krysiak, W. (2013). Influence of addition of green tea and green coffee extracts on the properties of fine yeast pastry fried products. Food Research International, 50, 149-160.

Chinma, C. E., Adewuyi O. and Abu J. O. (2009). Effect of germination on the chemical, functional and pasting properties of flour from brown and yellow varieties of tigernut (Cyperus esculentus). Food Research International, 42, 1004-1009.

Dayakar, R. B. and Bhargavi, G. (2017). Technology Involved in Quality of Biscuits: Influence of Factors and Impact on Processing - A Critical Review. International Journal of Pure \& Applied Bioscience, 5(4), 532-542.

Eke-Ejiofor, J., Beleya, E. A. and Onyenorah, N. I. (2014). The effect of processing methods on the functional and compositional properties of jackfruit seeds flour. International Journal of Nutrition and Food Sciences, 3(3), 166-173.

Elkhalifa, A. O. and Bernhardt, R. (2010). Influence of grain germination on functional properties of sorghum flour. Food Chemistry, 121, 387-392.

Francis, F. (1998). Colour analysis in: food S.S. (Nielsen ed.). Aspen Publishers, Gaithersburg. U.S.A.: 559-612.

Galla, N. R., Pamidighantam, P. R., Karakala, B., Gurusiddaiah, R. M. and Akula, S. (2007). Nutritional, textural and sensory quality of biscuits supplemented with spinach (Spinacia oleracea L.). International Journal of Gastronomy and Food Science, 7, 20-26.

Hallén, E., Ibanoglu, S. and Ainsworth, P. (2004). Effect of fermented/germinated cowpea flour addition on the rheological and baking properties of wheat flour. Journal of Food Engineering, 63, 177-184.

Hegazy, N. A., Kamil, M. M., Hussein, A. M. S. and Bareh, G. F. (2014). Chemical and technological properties of improved biscuit by chestnut flour. International Journal of Food and Nutritional Sciences, 3(6), 7-15.

Heinio, R. L., Noort, M. W. J., Katina, K., Alam, S. A., Sozer, N., de Kock, H. L., Hersleth, M. and Poutanen, K. (2016). Sensory characteristics of wholegrain and bran-rich cereal foods -A review. Trends in Food Science and Technology, 47, 25-38.

Hyun-Jung, C., Ahra, C. and Seung-Taik, L. (2014). Utilization of germinated and heatmoisture treated brown rices in sugar-snap cookies. LWT - Food Science and Technology, 57, 260-266.

Jimoh, K. O., Olurin, T. O. and Aina, J. O. (2009). Effect of drying methods on the rheological characteristics and colour of yam flours. African Journal of Biotechnology, 8(10), 2325-2328.

Korus, J., Witczak, M., Rafał, Z. and Juszczak, L. (2015). The influence of acorn flour on rheological properties of gluten-free dough and physical characteristics of the bread. European Food Research and Technology, 240, 1135-1143.

Mamat, H. and Hill, S. E. (2014). Effect of fat types on the structural and textural properties of dough and semi-sweet biscuit. Journal of Food Science and Technology, 
51(9), 1998-2005.

Mateos-Aparicio, I., Redondo-Cuenca, A. and Villanueva-Suárez, M. J. (2010). Isolation and characterisation of cell wall polysaccharides from legume by-products: Okara (soymilk residue), pea pod and broad bean pod. Food Chemistry, 122, 339-345.

Mogol, B. A. and Gökmen, V. (2014). Mitigation of acrylamide and hydroxymethylfurfural in biscuits using combined partial conventional baking and vacuum post-baking process: Preliminary study at the lab scale. Innovative Food Science and Emerging Technologies, 26, 265-270.

Onacik-Gür, S. Ż. A. and Jaroszewska, A. (2015). Effect of high-oleic sunflower oil and other pro-health ingredients on physical and sensory properties of biscuits. CyTAJournal of Food, 13(4), 621-628.

Oppong, D., Eric, A., Samuel, O. K., Eric, B. and Patrick, S. (2015). Proximate composition and some functional properties of soft wheat flour. International Journal of Innovative Research in Science, Engineering and Technology, 4(2), 23476710.

Ostermann-Porcel, M. V., Quiroga-Panelo, N., Rinaldoni, A. N. and Campderrós, M. E. (2017). Incorporation of okara into glutenfree cookies with high quality and nutritional value. Journal of Food Quality, 2017, 1-8.

Pandey, H. and Awasthi, P. (2015). Effect of processing techniques on nutritional compositio and antioxidant activity of fenugreek (Trigonella foenum-graecum) seeds flour. Journal of Food Science and Technology, 52(2), 1054-1060.

Popovic, B. M. D., Stajner, D. R., Zdero, O. S. and Galic, Z. (2013). Antioxidant characterization of oak extracts combining spectrophotometric assays and chemometrics. The Scientific World Journal, 2013, 1-8.

Ragaee, S., Abdel-Aal, E. S. M. and Noaman, M. (2006). Antioxidant activity and nutrient composition of selected cereals for food use. Food Chemistry, 98, 32-38.

Reddy, V., Urooj, A. and Kumar, A. (2005). Evaluation of antioxidant activity of some plant extracts and their application in biscuits. Food Chemistry, 90, 317-321.

Rizzello, C. G., Nionelli, L., Coda, R., Di, C. R. and Gobbetti, M. (2010). Use of sourdough fermented wheat germ for enhancing the nutritional, texture and sensory characteristics of the white bread. European Food Research and Technology, 230, 645654.

Sadowska, K. (2006). Owoce ostropestu plamistego jako prozdrowotny dodatek do pieczywa. Żywność. Nauka. Technologia. Jakość, 47(2), 290-296.

Shahat, M. S., Hussein, A. S. and Hady, E. A. (2016). Preparation of bread supplemented with milk thistle flour and its effect on acute hepatic damage caused by carbon tetrachloride in rats. Middle East Journal of Applied Sciences, 6(3), 531-540.

Sakin, M., Kaymak-Ertekin, F. and Ilicali, C. (2007). Modeling the moisture transfer during baking of white cake. Journal of Food Engineering, 80, 822-831.

Sakin-Yilmazer, M., Kemerli, T., Isleroglu, H., Ozdestan, O., Guven, G., Uren, A. and Kaymak-Ertekin, F. (2013). Baking kinetics of muffins in convection and steam assisted hybrid ovens (baking kinetics of muffin. . .). Journal of Food Engineering, 119, 483-489.

Serrem, C. A. (2010). Development of soy fortified sorghum and bread wheat biscuits as a supplementary food to combat protein energy malnutrition in young children. Department of Food Science. Faculty of Natural and Agricultural Sciences. University of Pretoria, South Africa : pp 78, p 54, 55, 89-91.

Sozer, N., Cicerelli, L., Heiniö, R. L. and Poutanen, K. (2014). Effect of wheat bran addition on in vitro starch digestibility, physicomechanical and sensory properties of biscuits. Journal of Cereal Science, 60, 105-113.

Youssef, H. M. K. E. and Mousa, R. M. A. 
(2012). Nutritional Assessment of Wheat Biscuits and Fortified Wheat Biscuits with Citrus Peels Powders. Food and Public Health, 2(1), 55-60.

Yusuf, A. A., Ayedun, H. and Sanni, L. O. (2008). Chemical composition and functional properties of raw and roasted Nigerian benniseed (Sesamum indicum) and bambara groundnut (Vigna subterranean). Food Chemistry, 111, 27-282.

Zouari, R., Besbes, S., Ellouze-Chaabouni, S. and Dhouha, G. (2016). Cookies from composite wheat-sesame peels flours: dough quality and effect of Bacillus subtilis SPB1 biosurfactant addition. Food Chemistry, 194, 758-769.

Zucco, F., Borsuk, Y. and Arntfield, S. D. (2011). Physical and nutritional evaluation of wheat cookies supplemented with pulse flours of different particle sizes. $L W T$ - Food Science and Technology, 44, 2070-2076.

\section{Acknowledgment}

Food Science Laboratory technicians are thanked for their assistance throughout the preparation of this work. 